Canadian

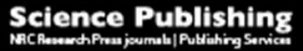

Botany

Botanique

\title{
Conifer demography in forest-grassland mosaics: a landscape-scale study over a 24-year period
}

\begin{tabular}{|r|l|}
\hline Journal: & Botany \\
\hline Manuscript ID & cjb-2016-0315.R2 \\
\hline Manuscript Type: & Article \\
\hline Date Submitted by the Author: & $10-$ Apr-2017 \\
\hline $\begin{array}{r}\text { Complete List of Authors: } \\
\text { Please Select from this Special } \\
\text { Issues list if applicable: }\end{array}$ & $\begin{array}{l}\text { Souza, Alexandre; Universidade Federal do Rio Grande do Norte, } \\
\text { Departamento de Ecologia }\end{array}$ \\
\hline Keyword: & $\begin{array}{l}\text { Atlantic forests, density-dependence, long-lived pioneers, satellite-based } \\
\text { analyses, mixed forests }\end{array}$ \\
\hline & \multicolumn{2}{|c|}{} \\
\hline
\end{tabular}

\section{SCHOLARONE $^{\text {tw }}$}

Manuscripts 


\section{Title Page}

Title: Conifer demography in forest-grassland mosaics: a landscape-scale study over a 24-year period

\section{Author}

Alexandre F. Souza (alexsouza@cb.ufrn.br, Tel. +55 8499137 1743)

Departamento de Ecologia, CB, Universidade Federal do Rio Grande do Norte, Campus Universitário, Lagoa Nova, Natal 59072-970, RN, Brazil. 
Abstract: Our understanding regarding the demography of adult conifers in forestgrassland mosaics is still limited. I studied the landscape-scale demography and spatial distribution of the conifer Araucaria angustifolia in a subtropical forest-grassland mosaic over a 24-year period. A. angustifolia is a long-lived pioneer that is expected to thrive in grasslands and forest edges better than in forest patches. I used the position of trees in aerial photographs taken in 1984 to analyze spatial patterns and a 2008 satellite image to estimate individual survivorship. Spatial distribution of trees in the grassland was aggregated and was not related to the distribution of trees in forest patches.

Survivorship was higher in forest patches than in grasslands, where it showed densitydependence. In forest patches, survivorship was positively related to both patch area and distance from forest edge. Crown breakage was more common in the grassland than in forest patches. In forest patches, it was positively related to crown size, number of conspecific neighbours, and patch area. Adult Araucaria seem to benefit from angiosperm-dominated neighbourhoods relative to isolation in grasslands. Densitydependent effects, known to be widespread among seeds and seedlings, were shown to be important to adult trees as well.

Key words: Atlantic forests; Brazil; density-dependence; long-lived pioneers; satellitebased analyses; mixed forests 


\section{Introduction}

Knowledge of adult tree demography is critical to understand how populations respond to environmental variability. However patterns can be missed because of insufficient sample size or time interval. Only a minority of studies have carried out demographic monitoring for more than a few years, while long-lived groups like conifers may experience negligible growth and mortality over short time scales (Beckert et al. 2014, Paludo et al. 2016). Dendrochronological analyses (e.g., Silva et al. 2009) allow for long-term assessment of growth patterns, but cannot provide information on survivorship or on ecological determinants of growth other than climatic variables. Hence, there is an important gap between short- and long-term information on tree demographic patterns and their dependency on ecological factors like habitat type and competition.

In landscapes containing mosaics of grasslands and mixed conifer-angiosperm forests, conifers play a pivotal role as both dominant forest species and as nurse plants facilitating forest succession in the grasslands through nucleation and forest patch edge expansion (Oliveira and Pillar 2005, Duarte et al. 2007, Korndörfer et al. 2014). They have been found to be long-lived pioneers capable of remaining in the community as established adults for centuries (Oliveira et al. 2010) but whose degree of shadeintolerance make them dependent upon large-scale disturbances for recruitment opportunities (Enright and Ogden 1995, Enright et al. 1999, Poorter et al. 2006, Brodribb et al. 2012). They frequently attain large adult sizes, and often form an emergent forest stratum (Souza 2007). This allows these species to remain dominant in 
the forest community despite their chronic regeneration failure. Understanding conifer demography in forest-grassland landscape mosaics is therefore key to foster ecological knowledge and management of both habitat types in such regions.

Several forces are expected to produce spatial aggregation of conifers colonizing grasslands from forest patches. While forest succession also occurs along forest edges (Oliveira and Pillar 2005), it may also take place through long-distance dispersal, which is facilitated by isolated trees already established in the grasslands or at forest nuclei (Duarte et al. 2006). Furthermore, several landscape patterns and processes are patchy and may influence spatial patterns of colonizing tree populations through effects on survivorship and growth. Examples are grassland burning for pasture renewal, past use by indigenous people, and the spatial distribution of rock outcrops, soil moisture, and nutrients (Garbin et al. 2006, Overbeck et al. 2007, Carlucci et al. 2011, Tokuoka and Hosogi 2012, Reis et al. 2014, Henderson et al. 2016). Conversely, negative density effects are expected to act against aggregation through increased mortality and reduced growth of close neighbors. Although density dependent effects are known to be widespread among seeds and seedlings (Harms et al. 2000), recent results have found negative effects of close neighbours on survivorship and growth of mature trees (Das et al. 2011, Lutz et al. 2014). Competition for soil nutrients (Silva et al. 2009, Cattaneo et al. 2013, Primicia et al. 2015) and mortality by natural enemies such as pathogens, seed predators, and herbivores (Bagchi et al. 2010, Steward and Beveridge 2010, Modes et al. 2012, Zandavalli and Dillenburg 2015) are some of the mechanisms underlying such negative density effects. The shallow and open crowns of South American conifers in the Araucaria genus (Fig. 1B-E) may make them susceptible to light competition 
through encroachment by the denser crowns of angiosperm trees (Pretzsch 2014). However, density may also produce positive effects by reducing wind velocity and increasing mechanical stability of neighbouring trees, thus promoting less wind-induced crown and stem breakage (Gardiner and Quine 2000, Primicia et al. 2015). Such positive effects should be more important for trees particularly exposed to the stresses imposed by the wind such as those in grasslands and emergent trees in forest patches. Finally, tree clusters in grasslands may reduce the risk of mortality by lightning (Primicia et al. 2015). These patterns and processes occur over a continuum of spatial and temporal scales within entire regions and are not easily assessed within the limited time and spatial frames of field studies (Ricklefs 2008).

In this study, I used aerial photographs and high-resolution satellite imagery to investigate the landscape-scale demography and spatial distribution of the conifer Araucaria angustifolia (hereafter Araucaria) over a 24-year period in a forest-grassland mosaic. I studied the ecotone between the mixed conifer-angiosperm forests and Pampa grasslands of southern Brazil. Landscapes in this region are characterized by speciesrich grasslands and forest patches of varying sizes (Souza et al. 2012). Specifically, I tested the following hypotheses on adult Araucaria: 1) In forest patches, survivorship and growth are higher near forest edges and in smaller forest patches compared to larger forest patches. Forest edges and small forest patches are shorter and more open than larger patches, and also have fewer shade-tolerant species (Laurance et al. 2011). This hypothesis was based on the premise that in forest edges and smaller forest patches the competitive pressure from the angiosperms on Araucaria for resources (e.g., light and nutrients) is reduced relative to larger forest patches and patch core areas. 2) Trees 
would exhibit aggregated spatial pattern at larger scales but random or less aggregated spatial patterns at small scales $(<500 \mathrm{~m})$ in grasslands, if negative density-dependent processes weaken the spatial aggregation of trees in this habitat. 3) Survivorship and growth are greater in grasslands relative to forest patches due to more light and soil nutrients availability in the grasslands; 4) Positive density effects reduce the occurrence of crown breakage in grasslands but not in forest patches. This hypothesis is based on the premise that trees in grasslands are more dependent on conspecific neighbours for mechanical stability than trees in forest patches. 5) Negative density effects reduce tree survivorship and growth in both forest patches and grasslands, but the effects are weaker in forest patches where I expect competition with angiosperms to override intraspecific effects. This expectation is based on the premise that the shallow and open crowns of Araucaria angustifolia may be encroached by the denser crowns of angiosperm trees.

\section{Materials and methods}

\section{Study area and species}

The studied forest-grassland system lies in southern South America near $30^{\circ} \mathrm{S}$ (Fig. 1A) in the São Francisco de Paula municipality, Rio Grande do Sul, Brazil, at the easternmost portion of the sul-riograndense highlands (elevation ca. $880 \mathrm{~m}$ ). The climate is humid subtropical lacking a true dry season, with temperate summers (Köppen type Cfb, Alvares et al. 2013), annual precipitation of ca. $2200 \mathrm{~mm}$, and mean 
annual temperature of $14.5^{\circ} \mathrm{C}$. Soils under both grasslands and forests are aluminumrich humic Cambisols developed on basaltic bedrock (Streck et al. 2008). Forest composition is transitional between the floras of southern and eastern South America, with ca. $30 \%$ of individual trees belonging to species restricted to austral-Antarctic and chilling-prone southern South America (Gonçalves and Souza 2014). Larger mixed conifer-angiosperm forest patches are rich in woody species and frequently dominated by Araucaria, despite extensive timber logging in the past ca. 150 years. Smaller patches (originated either from fragmentation or nucleation) are degraded by unregulated multiple use by farmers. These patches are thus kept at early successional stages, with higher angiosperm tree density, reduced basal area and hampered natural regeneration (Souza et al. 2012). In the last decades grasslands have been replaced by agriculture as well as by forest expansion, the latter occurring as a network of small patches in close contact with other land uses (Matos et al. 2016). Grasslands are occasionally burned by ranchers (Overbeck et al. 2007, Henderson et al. 2016), and punctuated by rock outcrops (Carlucci et al. 2011). They become colonized by Araucaria trees, which eventually form clusters and act as nurse trees in forest nucleation (Duarte et al. 2006). Forest patches do not experience burning, partly due to their closed-canopy physiognomy, the rainy regional climate, and the lack of silvopasture practices.

A dioecious and anemophilous species, Araucaria have dome-shaped architecture with shallow and open crowns (Fig. 1B-E). They produce large seeds that are heavily consumed and dispersed by an array of birds and mammals (Hartz et al. 2012). Despite their ability to withstand shade as seedlings (Duarte and Dillenburg 2000), they have 
been shown to be long-lived pioneers that require extensive canopy openings to reach maturity and whose abundance is negatively related to the abundance of angiosperm trees (Souza 2007, Souza et al. 2008, 2014). Information on specific angiosperm competitors is not yet available, partly due to the large number of potential competitor species (Souza et al. 2012) found 156 angiosperm species in the study area and surrounding forest patches).

\section{Data collection}

To assess demographic changes in the Araucaria populations, I compared aerial photographs taken in 1984 with a 2008 World View 1 satellite image. Both aerial photographs and high-resolution satellite images allow discrimination of highly conspicuous trees (Garzon-Lopez et al. 2013), such as Araucaria (Disperati and Oliveira Filho 2005). Both imagery systems yielded high-resolution images, in which Araucaria angustifolia crowns were clearly distinguished from other elements. No resolution or accuracy issues emerged. The 1984 data comprised two sets of 25 and 10 1:10,000 aerial photographs corresponding to two mosaics of the São Francisco de Paula rural landscape (total area $=55.63 \mathrm{~km}^{2}$, Fig. 2A). The areas depicted by the two photo mosaics were $5.34 \mathrm{~km}$ apart, were dominated by grasslands, and were crossed by the Caí River and its two small dams, the Salto (583-m long) and Blang (507-m long) dams. These two dammed reservoirs are narrow and do not significantly alter the surrounding grasslands. The 2008 data comprised two cloud-free World View 1 images with spatial resolution of $6.5 \mathrm{~m}$ (CE 90\%), encompassing the areas corresponding to the 
two aerial photo mosaics mentioned above, as well as a third area containing the São Francisco de Paula National Forest, which was used as a training area for the identification of Araucaria trees. The entire study region was encompassed in a single high-quality Quickbird satellite image from December 2007 (Digital-Globe, Longmont, CO, U.S.A.) available within the enhanced version of Google Earth. Both the aerial photographs and the World View 1 images were thus registered to this single georeferenced Google Earth image using ArcGIS ArcMap v. 9.1 software (ESRI 2006).

Data collection proceeded in three stages. The first stage was a training stage in which a technician checked whether Araucaria crowns mapped in 10 1-ha plots in the National Forest were also delineated on the 2008 World View image. After some trial and error all trees were correctly identified in the training dataset ${ }^{1}$. In the second stage the same technician carefully identified and marked the positions of all Araucaria crowns in the 1984 aerial photographs and saved these points as shape files. This second stage did not include data from the National Forest, which were used exclusively in the training phase. Sampling effort in the aerial photographs varied according to the abundance of Araucaria trees in the two habitats (grasslands and forest patches). In grasslands the number of Araucaria was relatively low and it was thus possible to mark all trees found in the images. In forest patches, however, Araucaria was much more abundant, forming nearly monospecific canopies in some forest patch sectors.

A procedure was thus established, using virtual transects to sample the Araucaria in forest patches with more than 50 individuals. The virtual transects were drawn and "sampled" on the aerial photographs using ArcGIS, not in the field. The

\footnotetext{
${ }^{1}$ See Supplementary Material for further information on the training procedure.
} 
virtual transects were linear and 200-m long, aligned with the longest side of each patch, and starting at randomly chosen points on the limits of each patch (Fig. 2C). All Araucaria whose crowns touched the transect were included in the sample, and additional parallel transects were used until a maximum of 50 trees per patch were sampled. In total, 41 virtual transects were used. Individual Araucaria sampled in the aerial photographs were assigned to a habitat category (grassland or forest), and measured for crown diameter, distance from the forest edge (for trees within forest patches only), and number of conspecific neighbours of first and second orders (described below). Crown diameters were measured using the "circle" tool in the Autodesk Map® 3D 2005 software. Araucaria crowns were clearly distinguishable from the background forest canopy or grassland due to their distinctive dome-shaped crowns. A first-order neighbour was defined as a tree whose crown touched or overlapped with the crown of a focal tree, while a second-order neighbour was a tree whose crown touched or overlapped the crown of a first order neighbour. The number of first- and second-order neighbours was used as a proxy for density effects.

Some forest patches ( $23.9 \%$ of 163 patches) were not entirely included in the aerial photographs, as is inevitable in such images. The areas of forest patches were thus estimated using the same 2007 Quickbird satellite image I used for georeferencing, which included the patch areas missing in the aerial photographs. This image was used exclusively for the two purposes of georeferencing and estimating the areas and perimeters of those forest patches whose images were not entirely in the aerial photographs. Patch area was estimated only after checking for temporal consistency in the shapes and sizes of those forest patches portions that appeared in the 1984 aerial 
photographs and in the 2007 Quickbird image as well as in the 2008 World View image. Forest patches were highly consistent between these years, showing almost no change in shape and size. Such temporal stability may be attributable to constant grassland management by landowners through regular grazing and sometimes burning of pastures, activities known to halt forest succession. The Google Earth Quickbird satellite image was not used to make any measurements regarding Araucaria trees, their distances to forest patch edges, or the sizes and shapes of forest patches visible in the 1984 aerial photographs. Sampling of Araucaria trees was carried out entirely in the aerial photographs and World View satellite imagery and did not include the parts of those forest patches missing in the photographs and which had to be estimated using the Google Earth Quickbird satellite image. Patch area estimation did not produce any loss of tree and demographic measurements. During the third stage of the data collection process all sampled trees, originally marked in the aerial photographs, were relocated in the 2008 World View image through their coordinates. Those that could not be relocated were assumed to have died. Those that were successfully relocated were considered survivors and had their crown diameters re-measured in order to estimate crown growth.

\section{Data analysis}

The parts of hypotheses 1 and 3 related to survivorship, and hypothesis 4 were tested using Generalized Linear Models (GLMs) with binomial errors, using survivorship or crown breakage occurrence as dependent variables. The part of 
hypotheses 1 and 3 related to crown growth were tested with Linear Regression. Hypothesis 2 was tested with a $G$-test and an ANOVA. Hypothesis 5 was tested with spatial point pattern analysis, which was also used to describe the spatial structure of the dependent variables in general. All analyses were carried out with software R 3.1.2 (R Core Team 2014). The relative degree of edge exposure for each forest patch was estimated using the non-dimensional shape index SI calculated as image $S I=P /\left(2 A^{0.5}\right)$, where $\mathrm{P}$ is the length of the patch's perimeter in $\mathrm{m}$, and $\mathrm{A}$ is the patch's area in $\mathrm{m}^{2}$ (Terborgh et al. 2006). SI is considered an index of the degree of relative edge such that forest patches with high SI (elongated polygons) have relatively more edge than islands with SI values approaching 1 (circular).

In Araucaria, crown growth is highly correlated with diameter growth (Nutto et al. 2005). Annual crown diameter growth per individual was calculated as: (Df-Di)/t where $\mathrm{D} f$ is the final diameter $(\mathrm{cm}), \mathrm{D} i$ is the initial diameter at the start of the interval, and $t=24$ years. I used the absolute growth rate as opposed to the relative growth rate (growth relative to initial size), which is sometimes used in studies of short-lived plants. However, the relative growth rate is less useful for the analysis of tree growth. This is because of an initial very rapid decline in RGRs with increasing tree size, which is caused by accumulation of non-photosynthetic material such as stems, branches, and roots (Bowman et al. 2013). Trees that suffered reduction in crown diameter (hereafter crown shrinkage) from 1984 to 2008 were analyzed separately from those that exhibited growth. I used crown shrinkage as a proxy for crown breakage, a reasonable assumption for the studied species (Nutto et al. 2005). Spatial autocorrelation in dependent variables was tested using Moran's I correlograms with twenty $500 \mathrm{~m}$ classes through function 
sp.correlogram of the spdep package (Bivand and Piras 2015). I found significant spatial autocorrelation for all dependent variables.

In order to choose the modeling approach that best accounted for the spatial autocorrelation in the data, I compared three different autocorrelation descriptors. First, I fitted a Generalized Linear Mixed Model (Zuur et al. 2009) to the data using the environmental variables as fixed factors and the affiliation of each individual Araucaria to either one of the two 1984 aerial photo mosaics as a random factor. Second, I fitted the data to autologistic or autonormal Generalized Linear Models (Besag 1974). Finally, I fitted the data to a GLM to which I added up to fifth-degree polynomial terms of the coordinates to the explanatory data (Borcard et al. 2011). Spatial autocorrelation analysis of residuals from each model was performed using Moran's I correlograms as described before, and the modeling approach that best controlled for spatial dependency was chosen. I only report results from polynomial GLMs, since only these produced residuals with no spatial autocorrelation. In all cases a full model was fitted first, followed by manual variable removal based on Akaike's information criterion (AIC, Akaike 1974) $)^{2}$.

Because my data consisted of maps of points, I used edge-corrected spatial point pattern analyses based on Ripley’s K-function (Ripley 1977), and its bivariate and marked extensions to test my second hypothesis as well as to assess the spatial structure of survivorship, crown growth and crown breakage and their associations with landscape features. The calculation of $\mathrm{K}$ for a range of distances ( $\mathrm{r}$ ) allows the study of spatial pattern at a range of scales. Bivariate analyses of the spatial interaction

\footnotetext{
${ }^{2}$ See the Supplementary Material for further details on spatial autocorrelation analyses.
} 
(association/repulsion) between two groups of points (e.g. two sub-populations) were based on the $\mathrm{K}_{12}$ test, where distances are computed between points of the two groups ( 1 and 2), instead of points within the same group. Marked analyses are used when a numerical mark like size or growth is attached to each point of the pattern (Diggle et al. 1983). I used bivariate analyses to test for spatial association between trees in the grassland and trees in forest patches, and marked analyses to test for spatial structure in crown growth. The derived variable $\mathrm{L}(\mathrm{r})$ ( or $\mathrm{L}_{12}(\mathrm{r})$ and gm(r) for the inter-type and marked analyses, respectively) enables the interpretation of the type of spatial pattern as a function of distance by plotting L(r) against $r$. For a completely random pattern $L(r)=$ 0 ; $\mathrm{L}(\mathrm{r})$ becomes negative when the pattern is regular and positive when trees are clustered. Similarly, values of $\mathrm{L}_{12}(\mathrm{r})=0$ indicate independence of the two types of points; $\mathrm{L}_{12}(\mathrm{r})<0$ indicate repulsion effects, while $\mathrm{L}_{12}(\mathrm{r})>0$ indicate attraction effects (Goreaud and Pélissier 2003). Significance of departure from a random spatial pattern of null association between pairs of points was estimated by a Monte Carlo procedure to simulate 1000 randomly generated plots of the same density and dimensions as the observed plot $^{3}$.

\section{Results}

Forested areas represented $30.1 \%$ of the aerial photo mosaics studied. They corresponded to 163 forest patches, most of which were small (area range $=0.05$ 1206.84 ha, median $=1.73$ ha, mean $\pm \mathrm{sd}=34.42 \pm 145.28$ ha). Forest patches had

\footnotetext{
${ }^{3}$ See the Supplementary Material for further details on spatial point pattern analyses.
} 
shapes ranging from long and narrow $(\mathrm{SI}=5424.51)$ to nearly circular $(\mathrm{SI}=1.88)$, but most of them were irregular, with shape indexes greater than the circular expectation of $1.0($ mean $\mathrm{SI} \pm \mathrm{sd}=49.31 \pm 450.51)$. A total of 1368 Araucaria trees were sampled in the studied landscape in 1984,1153 of which $(84.3 \%)$ in forest patches. Crown diameter estimates ranged from 3.05 to $20.80 \mathrm{~m}(9.59 \pm 2.66 \mathrm{~m})$. Spatial point pattern analyses indicated that Araucaria trees in the grassland ${ }^{4}$ were significantly aggregated at all scales, and that aggregation increased from small scales up to ca. $300 \mathrm{~m}$ (Fig. 3A). Bivariate point pattern analysis of Araucaria trees in the grassland and in forest patches produced $L_{12}(\mathrm{r})$ values smaller than the confidence interval for all tested spatial scales (Fig. 3B). This result indicated statistical independence between these two tree groups in space.

Survivorship between 1984 and 2008 was generally very high, but it was significantly higher among trees in forest patches $(96.7 \%)$ than in the grassland $(90.7 \%$, $G$-test $=12.98, \mathrm{df}=1, P<0.00032)$. Surviving trees in the grassland and in forest patches showed repulsion at distances around $100 \mathrm{~m}$, where values of $\mathrm{L}_{12}(\mathrm{r})$ were smaller than the null hypothesis confidence interval (Fig. 3C). Survivorship in the grassland showed no spatial autocorrelation, but significant density-dependence, being negatively related to the number of first-order conspecific neighbours, according with the best GLM model ${ }^{5}$ (Fig. 4). In forest patches, survivorship was not related to neighbour density, but increased with patch area and with distance to the forest patch edge $^{3}$ (Fig. 4). Spatial autocorrelation in the survivorship of trees in forest patches was accounted for using the inclusion of third-degree polynomials in the GLM model.

\footnotetext{
${ }^{4}$ Supplementary Material Fig. S2.

${ }^{5}$ Supplementary Material Tables S1 and S2.
} 
Average crown growth over the 24-year period was $3.44 \pm 2.50 \mathrm{~m}(0.14 \pm$ $\left.0.10 \mathrm{~m} \mathrm{year}^{-1}\right)$, and did not differ between trees in the grassland and in forest patches (ANOVA, $F=0.97, P=0.32$ ). In the grassland crown growth was spatially uncorrelated (Fig. 3D) and not related to any of the explanatory variables examined $\left(\mathrm{R}^{2}\right.$ $=0.02$ ). In forest patches, crown growth was negatively related to initial crown diameter in a linear regression model and exhibited a complex spatial structure, with the final model retaining fifth-degree polynomials $\left(\mathrm{R}^{2}=0.29\right.$, Table $\left.\mathrm{S} 1\right)$. Residual spatial autocorrelation in this model was negligible (Moran's $I=0.11$ ), with only one significant value that was not considered biologically significant given the large sample size (Koenig 1999).

A total of $30.1 \%$ of the trees that survived over the 24 -year study period exhibited crown breakage. Crown breakage was almost twice as common in the grassland (48.72\% of surviving trees) as in forest patches $(27.26 \%, G$-test $=33.81, P<$ 0.001). Crown breakage occurrence in the grassland was positively related to initial crown size and showed spatial dependency accounted for by third-degree polynomials (Tables S1 and S2). Crown breakage occurrence in forest patches was positively related to initial crown size, number of first-order neighbours, and patch area, and negatively related to second-order neighbours, showing spatial dependency accounted for using fifth-degree polynomials (Tables S1 and S2). Bivariate point pattern analysis for trees with crown breakage and crown growth ${ }^{6}$ in the grassland produced $L_{12}(\mathrm{r})$ values smaller than the confidence interval around $200 \mathrm{~m}$ and at distances $>800 \mathrm{~m}$, with marginally

\footnotetext{
${ }^{6}$ Supplementary Material Fig. S3.
} 
significant negative values in between (Fig. 3E). This result indicated repulsion between these two tree groups at these scales.

\section{Discussion}

In this study I detected landscape-scale demographic and spatial patterns in the dominant conifer Araucaria angustifolia over a time interval (24 years) that, although short relative to conifer's lifespan (Oliveira et al. 2009), is substantially longer than most demographic studies in the literature. Long-lived groups such as conifers may present negligible growth and mortality over the few years during which most research projects carry out demographic monitoring (Silva et al. 2009, Beckert et al. 2014, Paludo et al. 2016). Dendroecological studies span longer time-scales but do not allow for the assessment of survivorship or its relationship with habitat variables like forest patch size. Conifer demography in mixed forests has been successfully explained in the framework of the long-lived pioneer ecological strategy (Enright and Ogden 1995, Enright et al. 1999, Poorter et al. 2006, Brodribb et al. 2012). In this framework cohorts of large-sized, long-lived, and light-demanding conifers establish following severe disturbances. They are followed by successive cohorts of angiosperm species that dominate the forest understory and suppress conifer regeneration, which becomes restricted to formed by multiple treefall gaps. Because of their longevity and large sizes, conifers remain dominant in these forests for long time periods (frequently centuries, Oliveira et al. 2010), although demographically functioning as remnant populations that lack sufficient regeneration. While substantial evidence supports the regeneration 
component of this model (Duarte and Dillenburg 2000, Souza et al. 2008, Steward and Beveridge 2010, Paludo et al. 2016), our understanding of the demography of adult trees is limited.

My first hypothesis stated that survivorship and growth are increased near forest edges and in smaller forest patches compared to larger patches. However, whereas the regeneration of long-lived pioneers has been shown to be hampered by competition with broad-leaved species (Duarte et al. 2002, Souza 2007, Souza et al. 2008), adult Araucaria seemed to benefit from angiosperm-dominated neighbourhoods. Survivorship decreased near forest edges, in accordance with findings for late seral forest species (Laurance et al. 2011). Forest edges have increased exposure to windshear, windstorms, and wind turbulence which sharply elevate rates of tree mortality and damage (Laurance et al. 2011), and make the edge environment more similar to open grasslands, which had lower rates of survivorship. This indicates the emergent canopies adult Araucaria form above the lower angiosperm canopies (Souza 2007) probably precludes competition with angiosperms for light (Poorter et al. 2006, Pretzsch 2014). This idea is reinforced by the lack of relationship between Araucaria crown growth and distance to forest edge and patch area, contrary to my first and second hypotheses, as well as by the reduced chances of crown breakage in Araucaria trees with angiosperm-dominated neighbourhoods. Larger forest patches have larger and taller emergent conifers (Souza 2007, Souza et al. 2012), and this is likely to increase crown exposure of adult Araucaria. The main cause of adult Araucaria death in forests is tree fall during windstorms (Beckert et al. 2014). Therefore, neighbouring angiosperm canopies may produce positive effects by reducing wind-induced crown and 
stem breakage through increased mechanical stability, mainly in larger and undegraded patches (Gardiner and Quine 2000, Primicia et al. 2015).

Crown growth exhibited complex spatial structure as indicated by the fifthdegree polynomials needed to produce homogeneous residuals in the linear regression. This may indicate that several non-measured factors influence growth, such as genetic variation (Harding and Woolaston 1991), species composition of tree neighbourhoods (Liu et al. 2012), structural development of forests (Souza and Martins 2006), and pathogen infestation (Steward and Beveridge 2010, Modes et al. 2012, Zandavalli and Dillenburg 2015). Furthermore, dendrochronological analyses have shown that drought and high temperatures can limit growth of Araucaria in both grasslands and forests (Silva et al. 2009, Zanon and Finger 2010). Climatic factors, however, are unlikely to have had a major influence on growth in my study because the study period was rainy with mild temperatures relative to the early $20^{\text {th }}$ century in the São Francisco de Paula region (Silva et al. 2009).

My second hypothesis, stating that trees should present aggregated spatial pattern at larger scales but random or less aggregated spatial patterns at small scales $(<$ $500 \mathrm{~m}$ ) in grasslands, was confirmed. Araucaria seeds are dispersed into grasslands by birds (Duarte et al. 2007, Hartz et al. 2012) and find safe sites in rock outcrops (Carlucci et al. 2011) and in the understory of isolated trees and shrubs (Duarte et al. 2006). These elements are clustered in natural landscapes (Tokuoka and Hosogi 2012). Furthermore, coarse-scale factors that promote establishment and growth, such as soil nutrients and moisture, often occur as patches (Garbin et al. 2006, Matos et al. 2016). The maximum aggregation of Araucaria at scales larger than 300 m likely reflects recruitment 
structuring by such large-scale factors, coupled with human effects like periodic grassland burning for pasture renewal and cattle grazing (Henderson et al. 2016). Early indigenous people historically managed species of the genus Araucaria as a strategic food resource (Reis et al. 2014). However, it is unlikely that current Araucaria distribution patterns reflect hunter-gatherer activities due to widespread logging of Araucaria during the $19^{\text {th }}$ and $20^{\text {th }}$ centuries (Cabral and Cesco 2008). Contemporary grassland disturbance through fire and cattle management, on the other hand, is believed to prevent forest expansion by suppressing tree establishment (Blanco et al. 2014). In grasslands protected from these disturbances, forest succession is widespread along forest patch edges (Oliveira and Pillar 2005). Indeed, generalized forest expansion has taken place in southern Brazilian grasslands in the last decades due to land ownership concentration and rural exodus (Matos et al. 2016). The repulsion or lack of association I found between trees in the grasslands and in forest patches may result from suppression of forest succession along forest edges by landowners activities, blurring the spatial signature of grassland colonization from forest patches.

My third hypothesis stated that survivorship and growth should increase in grasslands relative to forest patches. However, survivorship was lower in the grassland than in forest patches. Furthermore, Araucaria abundance in the grassland was much lower than in forest patches, and crown breakage was almost twice as common in the grassland than in forest patches. These results suggest that, despite Araucaria being the main nurse plant colonizing the grasslands and leading forest nucleation (Korndörfer et al. 2014), grasslands represent harsh habitats for this species. Trees in grasslands are exposed to strong winds, lightning, and human-induced fire (Blanco et al. 2014, 
Primicia et al. 2015, Henderson et al. 2016). Trees in the grassland may also suffer from nutrient limitation (Silva et al. 2009, but see Garbin, Zandavalli \& Dillenburg 2006). These results thus contradict my fourth hypothesis, that positive density effects reduce the occurrence of crown breakage in grasslands, but not in forest patches. The mechanism underlying this hypothesis, that tree neighbours may produce increased mechanical stability, seems to hold true in forest patches but not in grasslands. An important implication is that Araucaria conspecifics in neighbourhoods are unlikely to exert positive density effects, while angiosperm neighbourhoods, as commented above, may have positive rather than negative effects.

My fifth hypothesis stated that negative density effects should reduce tree survivorship and growth in both forest patches and grasslands, but the effects are weaker in forest patches. This hypothesis received partial support, since survivorship (but not growth) in the grassland was negatively correlated with density. Competition for soil nutrients (Silva et al. 2009, Cattaneo et al. 2013, Primicia et al. 2015) and overcompensating mortality by natural enemies such as pathogens, seed predators, and herbivores (Bagchi et al. 2010, Steward and Beveridge 2010, Modes et al. 2012, Zandavalli and Dillenburg 2015) are some of the mechanisms that may underlie such negative density effects. Lower density of mycorrhizal fungi in grasslands relative to forests (Breuninger et al. 2000, Leal and Lorscheitter 2007) may reduce nutrient uptake by mature Araucaria trees, which are dependent on fungal mutualists for nutrient supply and growth (Zandavalli et al. 2004). Supposed positive density effects through reduced wind-induced crown and stem breakage or dilution of lightning probability are unlikely to occur or prevail in grasslands. Negative density dependent effects, on the other hand, 
may contribute to the reduced spatial aggregation of trees at small spatial scales in grasslands through reduced survivorship of neighbouring trees (Lutz et al. 2014). Random or weakly aggregated Araucaria distribution may also reflect homogeneous local environments (Souza et al. 2008, Machado et al. 2012).

Altogether, my results provide a more complete view of the ecology of Araucaria in particular, and probably of long-lived pioneers in general, in forestgrassland landscapes. While conifer recruitment has been shown to be suppressed in closed-canopy forest habitats, these same habitats are more favorable to adults than open grasslands. Conifers in southern South America may have complex positive and negative interactions with angiosperm species. In my study, adult Araucaria displayed greater survivorship and reduced crown breakage in mixed conifer-broadleaved forests compared to grasslands. Furthermore, although density dependent effects are known to be widespread among seeds and seedlings (Harms et al. 2000), my results lend support to recent evidence for density-dependent effects acting on the demography of adult trees mediated by their spatial distribution (Das et al. 2011, Lutz et al. 2014). Finally, the present results strengthen the argument of Ricklefs (2008) that population patterns occur over a continuum of spatial and temporal scales within entire regions and are not easily assessed within the limited time and spatial frames of field studies alone.

\section{Acknowledgements}

Financial support was provided by the Brazilian National Council of Technological and Scientific Development (CNPq) through grant 483336/2007-6 (Universal 0315/2007) 
and by Universidade do Vale do Rio dos Sinos (UNISINOS) through a UNIBIC undergraduate scholarship that provided for technical support. I am grateful to Mirela Motta for her dedicated image processing throughout the performance of this work. Alessandro Otto Reinhardt kindly provided technical support. Comments by Mark Dixon, Robert J. Arntd, and two anonymous referees greatly helped to improve an earlier version of this manuscript. Mark Dixon and Robert J. Arntd also kindly reviewed the English.

\section{References}

Akaike, H. 1974. A new look at the statistical model identification. IEEE Trans. Autom. Control 19: 716-723.

Alvares, C.A., Stape, J.L., Sentelhas, P.C., De Moraes Gonçalves, J.L., and Sparovek, G. 2013. Köppen's climate classification map for Brazil. Meteorol. Zeitschrift 22(6): 711-728. doi:10.1127/0941-2948/2013/0507.

Bagchi, R., Swinfield, T., Gallery, R.E., Lewis, O.T., Gripenberg, S., Narayan, L., and Freckleton, R.P. 2010. Testing the Janzen-Connell mechanism: Pathogens cause overcompensating density dependence in a tropical tree. Ecol. Lett. 13(10): 12621269. doi:10.1111/j.1461-0248.2010.01520.x.

Beckert, S.M., Rosot, M.A.D., and Rosot, N.C. 2014. Crescimento e dinâmica de Araucaria angustifolia (Bert.) O. Ktze. em fragmento de Floresta Ombrófila Mista. Sci. For. Sci. 42(102): 209-218.

Besag, J. 1974. Spatial interaction and the statistical analysis of lattice systems. J. R. Stat. Soc. Ser. B 36: 192-236.

Bivand, R., and Piras, G. 2015. Comparing implementations of estimation methods for spatial econometrics. J. Stat. Softw. 63(18): 1-36.

Blanco, C.C., Scheiter, S., Sosinski, E., Fidelis, A., Anand, M., and Pillar, V.D. 2014. Feedbacks between vegetation and disturbance processes promote long-term persistence of forest-grassland mosaics in south Brazil. Ecol. Modell. 291(November): 224-232. doi:10.1016/j.ecolmodel.2014.07.024.

Borcard, D., Gillet, F., and Legendre, P. 2011. Numerical ecology with R. Springer, New York.

Bowman, D.M.J.S., Brienen, R.J.W., Gloor, E., Phillips, O.L., and Prior, L.D. 2013. Detecting trends in tree growth: not so simple. Trends Plant Sci. 18(1): 11-17. Elsevier Ltd. doi:10.1016/j.tplants.2012.08.005.

Breuninger, M., Einig, W., Magel, E., Cardoso, E., and Hampp, R. 2000. Mycorrhiza of 
Brazil Pine $(<\mathrm{i}>$ Araucaria angustifolia $<\mathrm{i}>$ [Bert. O. Ktze.]). Plant Biol. 2(1): 4-10. doi:10.1055/s-2000-9177.

Brodribb, T.J., Pittermann, J., and Coomes, D.A. 2012. Elegance versus Speed: Examining the Competition between Conifer and Angiosperm Trees. Int. J. Plant Sci. 173(6): 673-694. doi:10.1086/666005.

Cabral, D.C., and Cesco, S. 2008. Notas para uma história da exploração madeireira na Mata Atlântica do sul-sudeste. Ambient. Soc. XI(1): 33-48.

Carlucci, M.B., Duarte, L. da S., and Pillar, V.D. 2011. Nurse rocks influence forest expansion over native grassland in southern Brazil. J. Veg. Sci. 22(1): 111-119. doi:10.1111/j.1654-1103.2010.01229.x.

Cattaneo, N., Pahr, N., Fassola, H., Leporati, J., and Bogino, S. 2013. Sex-related, growth-climate association of Araucaria angustifolia in the neotropical ombrophilous woodlands of Argentina. Dendrochronologia 31(3): 147-152. Elsevier GmbH. doi:10.1016/j.dendro.2013.01.005.

Das, A., Battles, J., Stephenson, N.L., and van Mantgem, P.J. 2011. The contribution of competition to tree mortality in old-growth coniferous forests. For. Ecol. Manage. 261(7): 1203-1213. doi:10.1016/j.foreco.2010.12.035.

Diggle, P.J., Sibson, R., and Cohen, J.E. 1983. Statistical analysis of spatial point patterns. Academic Press, Lodon. Available from 243.

Disperati, A.A., and Oliveira Filho, P.C. 2005. Delineamento de copas de árvores em fotografias aéreas de alta resolução, através de suas sombras periféricas: estudo de caso na Floresta Ombrófila Mista. Rev. Árvore 29(2): 195-202.

Duarte, L.S., Carlucci, M.B., Hartz, S.M., and Pillar, V.D. 2007. Plant dispersal strategies and the colonization of Araucaria forest patches in a grassland-forest mosaic. J. Veg. Sci. 18: 847-858.

Duarte, L.S., and Dillenburg, L.R. 2000. Ecophysiological responses of Araucaria angustifolia (Araucariaceae) seedlings to different irradiance levels. Aust. J. Bot. 48: 531-537.

Duarte, L.S., Dillenburg, L.R., and Rosa, L.M.G. 2002. Assessing the role of light availability in the regeneration of Araucaria angustifolia (Araucariaceae). Aust. J. Ecol. 50: 741-751.

Duarte, L.S., Santos, M.M.G., Hartz, S.M., and Pillar, V.D. 2006. Role of nurse plants in Araucaria Forest expansion over grassland in south Brazil. Austral Ecol. 31: 520-528. Available from 1866.

Enright, N., and Ogden, J. 1995. The southern conifers - a synthesis. In Ecology of the southern conifers. Edited by N. Enright and R. Hill. Smithsonian Institution Press, Washington. pp. 271-287.

Enright, N.J., Ogden, J., and Rigg, L.S. 1999. Dynamics of forests with Araucariaceae in the western Pacific. J. Veg. Sci. 10: 793-804. Available from 1754.

ESRI. 2006. ArcMap 9.2 . Environmental Systems Research Institute, Inc., USA.

Garbin, M.L., Zandavalli, R.B., and Dillenburg, L.R. 2006. Soil patches of inorganic nitrogen in subtropical Brazilian plant communities with Araucaria angustifolia. Plant Soil 286: 323-337.

Gardiner, B.A., and Quine, C.P. 2000. Management of forest to reduce the risk of abiotic damage -- a review with particular reference to the effects of strong winds. For. Ecol. Manage. 135: 261-277. doi:10.1016/S0378-1127(00)00285-1. 
Garzon-Lopez, C.X., Bohlman, S.A., Olff, H., and Jansen, P.A. 2013. Mapping tropical forest trees using high-resolution aerial digital photographs. Biotropica 45(3): 308316. doi:10.1111/btp.12009.

Gonçalves, E.T., and Souza, A.F. 2014. Floristic variation in ecotonal areas: Patterns, determinants and biogeographic origins of subtropical forests in South America. Austral Ecol. 39(1): 122-134. doi:10.1111/aec.12051.

Goreaud, F., and Pélissier, R. 2003. Avoiding misinterpretation of biotic interactions with the intertype K 12 -function: population independence vs. random labelling hypotheses. J. Veg. Sci. 14(5): 681-692. doi:10.1111/j.1654-1103.2003.tb02200.x.

Harding, K.J., and Woolaston, R.R. 1991. Genetic parameters for wood and growth properties in Araucaria Cunninghamii. Silvae Genet. 40(5/6): 232-237.

Harms, K.E., Wrght, S.J., Calderón, O., Hern ndez, A., and Herre, E.A. 2000. Pervasive density-dependent recruitment enhances seedling diversity in a tropical forest. Nature 404(6777): 493-495.

Hartz, S.M., Pinheiro, G.C., de Mendonça-Lima, A., and Duarte, L. da S. 2012. The potential role of migratory birds in the expansion of araucaria forest. Nat. a Conserv. 10(1): 52-56. doi:10.4322/natcon.2012.009.

Henderson, K.A., Reis, M., Blanco, C.C., Pillar, V.D., Printes, R.C., Bauch, C.T., and Anand, M. 2016. Landowner perceptions of the value of natural forest and natural grassland in a mosaic ecosystem in southern Brazil. Sustain. Sci. 11(2): 321-330. doi:10.1007/s11625-015-0319-3.

Koenig, W.D. 1999. Spatial autosorrelation of ecological phenomena. Tree 14(1): 2226.

Korndörfer, C., Dillenburg, L., and Duarte, L. 2014. Assessing the potential of Araucaria angustifolia (Araucariaceae) as a nurse plant in highland grasslands of south Brazil. New Zeal. J. Bot. 53(1): 5-14. doi:10.1080/0028825X.2014.979837.

Laurance, W.F., Camargo, J.L.C., Luizão, R.C.C., Laurance, S.G., Pimm, S.L., Bruna, E.M., Stouffer, P.C., Bruce Williamson, G., Benítez-Malvido, J., Vasconcelos, H.L., Van Houtan, K.S., Zartman, C.E., Boyle, S.A., Didham, R.K., Andrade, A., and Lovejoy, T.E. 2011. The fate of Amazonian forest fragments: A 32-year investigation. Biol. Conserv. 144(1): 56-67. doi:10.1016/j.biocon.2010.09.021.

Leal, M.G., and Lorscheitter, M.L. 2007. Plant succession in a forest on the Lower Northeast Slope of Serra Geral, Rio Grande do Sul, and Holocene palaeoenvironments, Southern Brazil. Acta Bot. Brasilica 21(1): 1-10. doi:10.1590/S0102-33062007000100001.

Liu, X., Liang, M., Etienne, R.S., Wang, Y., Staehelin, C., and Yu, S. 2012. Experimental evidence for a phylogenetic Janzen-Connell effect in a subtropical forest. Ecol. Lett. 15(2): 111-118. doi:10.1111/j.1461-0248.2011.01715.x.

Lutz, J.A., Larson, A.J., Furniss, T.J., Donato, D.C., Freund, J.A., Swanson, M.E., Bible, K.J., Chen, J., and Franklin, J.F. 2014. Spatially nonrandom tree mortality and ingrowth maintain equilibrium pattern in an old-growth Pseudotsuga-Tsuga forest. Ecology 95(8): 2047-2054. doi:10.1890/14-0157.1.

Machado, S. do A., Santos, A.A.P. dos, Zamin, N.T., and Nascimento, R.G.M. 2012. Distribuição espacial de um fragmento de Floresta Ombrófila Mista Montana. Ciência Rural 42(6): 1013-1019. Available from http://www.scielo.br/pdf/cr/2012nahead/a15312cr4493.pdf. 
Matos, D.U. de, Souza, A.F., Moura, R.G., and Crossetti, L.O. 2016. Habitat dynamics in subtropical South America: Socioeconomic determinants and landscape patterns at a forest-grassland ecotone. Neotrop. Biol. Conserv. 11(1): 2-12. doi:10.4013/nbc.2016.111.01.

Modes, K.S., Lazarotto, M., Beltrame, R., and Vivian, M.A. 2012. Resistência natural das madeiras de sete espécies florestais ao fungo Pycnoporus sanguineus causador da podridão-branca. Cerne 18(3): 407-411.

Nutto, L., Spathelf, P., and Rogers, R. 2005. Managing diameter growth and natural pruning of Parana pine, Araucaria angustifolia (Bert.) O Ktze., to produce high value timber. Ann. For. Sci. 62(2): 163-173. doi:10.1051/forest:2005008.

Oliveira, J.M., and Pillar, V.D. 2005. Vegetation dynamics on mosaics of Campos and Araucaria forest between 1974 and 1999 in Southern Brazil. Community Ecol. 5(2): 197-202. doi:10.1556/ComEc.5.2004.2.8.

Oliveira, J.M., Roig, F.A., and Pillar, V.P. 2010. Climatic signals in tree-rings of Araucaria angustifolia in the southern Brazilian highlands. Austral Ecol. 35: 134147. doi:10.1111/j.1442-9993.2009.02018.x.

Oliveira, J.M., Santarosa, E., Pillar, V.P., and Roig, F.A. 2009. Seasonal cambium activity in the subtropical rain forest tree Araucaria angustifolia. Trees 23: 107115. doi:10.1007/s00468-008-0259-y.

Overbeck, G.E., Müller, S.C., Fidelis, A., Pfadenhauer, J., Pillar, V.D., Blanco, C.C., Boldrini, I.I., Both, R., and Forneck, E.D. 2007. Brazil's neglected biome: the south Brazilian campos. Perspect. Plant Ecol. Evol. Syst. 9: 101-116. Available from 2030.

Paludo, G.F., Lauterjung, M.B., Reis, M.S. dos, and Mantovani, A. 2016. Inferring population trends of Araucaria angustifolia (Araucariaceae) using a transition matrix model in an old-growth forest. South. For. a J. For. Sci. 2620(March). doi:10.2989/20702620.2015.1136506.

Poorter, L., Bongers, L., and Bongers, F. 2006. Architecture of 54 moist-forest tree species: traits, trade-offs, and functional groups. Ecology 87(5): 1289-1301. doi:10.1890/0012-9658(2006)87[1289:AOMTST]2.0.CO;2.

Pretzsch, H. 2014. Canopy space filling and tree crown morphology in mixed-species stands compared with monocultures. For. Ecol. Manage. 327: 251-264. Elsevier B.V. doi:10.1016/j.foreco.2014.04.027.

Primicia, I., Camarero, J.J., Janda, P., Cada, V., Morrissey, R.C., Trotsiuk, V., Bace, R., Teodosiu, M., and Svoboda, M. 2015. Age, competition, disturbance and elevation effects on tree and stand growth response of primary Picea abies forest to climate. For. Ecol. Manage. 354: 77-86. doi:10.1016/j.foreco.2015.06.034.

Reis, M.S., Ladio, A., and Peroni, N. 2014. Landscapes with Araucaria in South America: Evidence for a cultural dimension. Ecol. Soc. 19(2). doi:10.5751/ES06163-190243.

Ricklefs, R.E. 2008. Disintegration of the ecological community. Am. Nat. 172(6): 741-750. doi:10.1086/593002.

Ripley, B. 1977. Modelling spatial patterns. J. R. Stat. Soc. B 39: 172-212.

Silva, L.C.R., Anand, M., Oliveira, J.M., and Pillar, V.D. 2009. Past century changes in Araucaria angustifolia (Bertol.) Kuntze water use efficiency and growth in forest and grassland ecosystems of southern Brazil: Implications for forest expansion. 
Glob. Chang. Biol. 15(10): 2387-2396. doi:10.1111/j.1365-2486.2009.01859.x.

Souza, A.F. 2007. Ecological interpretation of multiple population size structures in trees: The case of Araucaria angustifolia in South America. Austral Ecol. 32: 524533.

Souza, A.F., Cortez, L.S.R., and Longhi, S.J. 2012. Native forest management in subtropical South America: long-term effects of logging and multiple-use on forest structure and diversity. Biodivers. Conserv. 21(8): 1953-1969. doi:10.1007/s10531-012-0287-1.

Souza, A.F., Forgiarini, C., Longhi, S.J., and Brena, D.A. 2008. Regeneration patterns of a long-lived dominant conifer and the effects of logging in southern South America. Acta Oecologica 34: 221-232.

Souza, A.F., Forgiarini, C., Longhi, S.J., and Oliveira, J.M. 2014. Detecting ecological groups from traits: a classification of subtropical tree species based on ecological strategies. Brazilian J. Bot. doi:10.1007/s40415-014-0084-z.

Souza, A.F., and Martins, F.R. 2006. Demography of the clonal palm Geonoma brevispatha in a Neotropical swamp forest. Austral Ecol. 31: 869-881.

Steward, G., and Beveridge, A. 2010. A review of New Zealand kauri (Agatis australis (D.Don) Lindl.): its ecology, history, growth and potential for management for timber. New Zeal. J. For. Sci. 40: 33-59. Available from http://www.scopus.com/inward/record.url?eid=2-s2.077955440077\& partnerID=tZOtx3y1.

Streck, E.V., Kämpf, N., Dalmolin, R.S.D., Klant, E., Nascimento, P.C., Schneider, P., Giasson, E., and Pinto, L.F.S. 2008. Solos do Rio Grande do Sul. EMATER/RS, Porto Alegre.

Terborgh, J., Feeley, K., Silman, M., Nunez, P., and Balukjian, B. 2006. Vegetation dynamics of predator-free land-bridge islands. J. Ecol. 94(2): 253-263. doi:10.1111/j.1365-2745.2006.01106.x.

Tokuoka, Y., and Hosogi, D. 2012. Spatial distribution and management of isolated woody plants traditionally used as farmland boundary markers in Ibaraki Prefecture, Japan. Springerplus 1(1): 57. doi:10.1186/2193-1801-1-57.

Zandavalli, R., and Dillenburg, L. 2015. Response of Araucaria angustifolia seedlings to root competition in three different plant communities of southern Brazil. New Zeal. J. Bot. 53(3): 139-154. doi:10.1080/0028825X.2015.1043922.

Zandavalli, R.B., Dillenburg, L.R., and Souza, P.V.D. 2004. Growth responses of Araucaria angustifolia (Araucariaceae) to inoculation with the mycorrhizal fungus Glomus clarum. Appl. Soil Ecol. 25(3): 245-255. Available from 1748.

Zanon, M.L.B., and Finger, C.A.G. 2010. Relação de variáveis meteorológicas com o crescimento das árvores de araucaria angustifolia (Bertol.) Kuntze em povoamentos implantados. Cienc. Florest. 20(3): 467-476. doi:10.5902/198050982061.

Zuur, A.F., Ieno, E.N., Walker, N., Saveliev, A.A., and Smith, G.M. 2009. Mixed effects models and extensions in ecology with R. Springer New York, New York, NY. doi:10.1007/978-0-387-87458-6.

\section{Figures captions}


Fig. 1. A) Distribution of the Atlantic Forest and Pampa grasslands ecoregions in South America, and the location of the study area (black dot). The studied landscape lies at the transition zone between the two ecoregions. Map elaborated by the author with R. B - E: Views of Araucaria angustifolia trees (foreground) growing in the studied habitats in differing ecological circumstances: clusters in the grassland (B), isolated on a rock outcrop in the grassland (C), on the edge of a medium-sized forest patch (D), and within a small forest patch (E).

Fig. 2. A) Aerial photo mosaics of the study area at São Francisco de Paula, southern Brazil. B) View of aerial photograph section with Araucaria angustifolia trees isolated in the grassland (arrows). C) View of aerial photograph section with sampled Araucaria angustifolia trees (dots) in forest patches. Note the presence of trees sampled along virtual transects in the two larger forest patches as well as individual trees isolated in the grassland.

Fig. 3. Spatial point pattern analyses. A) Univariate $L$ function for all trees in the grassland (solid line). B) Bivariate $L$ function estimated for trees in the grassland and in forest patches. C) Bivariate $L$ function estimated for surviving and dying trees in the grassland. D) Crown growth marked $\mathrm{Km}$ function estimated for trees in the grassland. E) Bivariate $L$ function estimated for trees with crown breakage and crown growth in the grassland. All graphs with a 99\% local confidence envelope obtained from 1000 Monte Carlo simulations (dashed lines). The horizontal dotted lines mark the absolute zero $L$ or $K m$ values. Graph regions where the spatial function is above the upper limit 
of the confidence envelope indicate significant aggregation ( $L$ or $K m$ functions) or attraction (bivariate $L$ function) at the corresponding spatial scale in the horizontal axis. Graph regions where the spatial function is below the lower limit of the confidence envelope indicate significant uniform distribution ( $L$ or $\mathrm{Km}$ functions) or repulsion (bivariate $L$ function) at the corresponding spatial scale in the horizontal axis

Fig. 4. Fitted binomial GLM models and 95\% confidence bands (shaded areas) for the survival probability of adults of the conifer Araucaria angustifolia on forest patch area and distance to forest edge in forest patches and on the number of conspecific neighbours in grasslands in southern South America. 

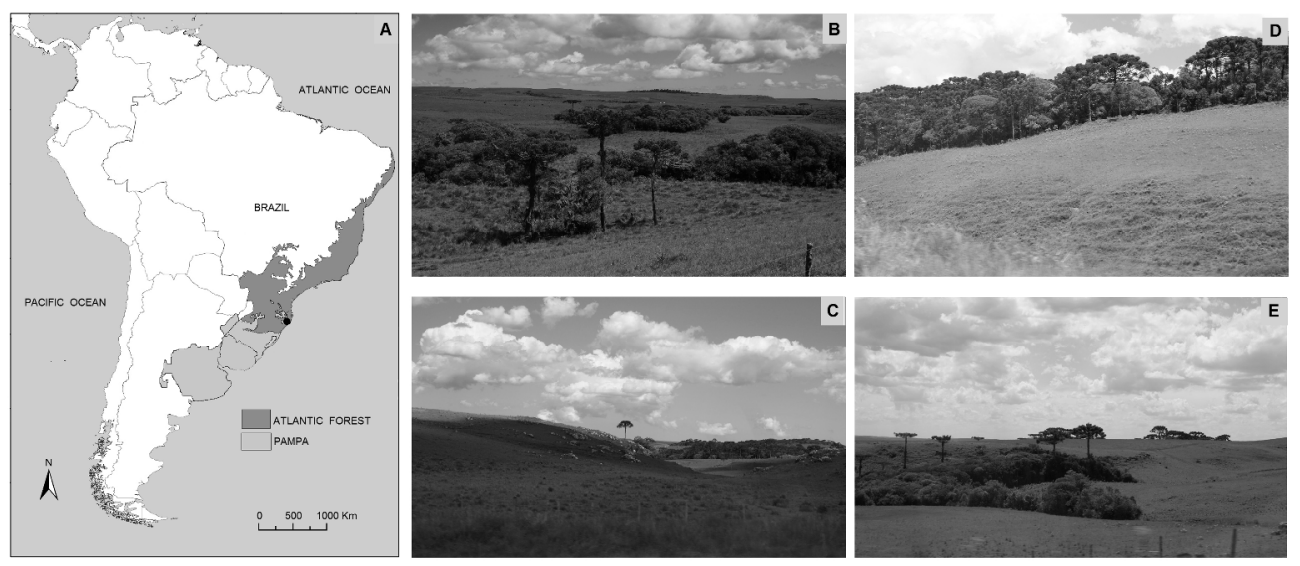

Fig. 1. A) Distribution of the Atlantic Forest and Pampa grasslands ecoregions in South America, and the location of the study area (black dot). The studied landscape lies at the transition zone between the two ecoregions. Map elaborated by the author with R. B - E: Views of Araucaria angustifolia trees (foreground) growing in the studied habitats in differing ecological circumstances: clusters in the grassland (B), isolated on a rock outcrop in the grassland (C), on the edge of a medium-sized forest patch (D), and within a small forest patch (E).

$311 \times 135 \mathrm{~mm}(300 \times 300 \mathrm{DPI})$ 

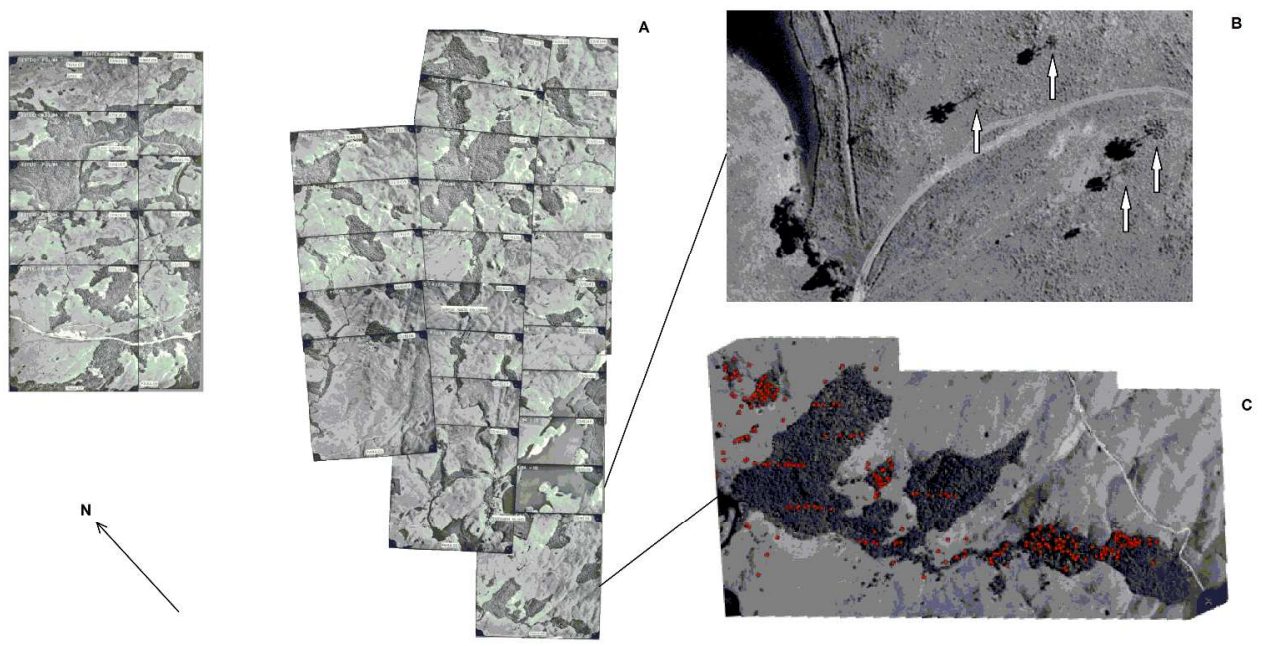

Fig. 2. A) Aerial photo mosaics of the study area at São Francisco de Paula, southern Brazil. B) View of aerial photograph section with Araucaria angustifolia trees isolated in the grassland (arrows). C) View of aerial photograph section with sampled Araucaria angustifolia trees (dots) in forest patches. Note the presence of trees sampled along virtual transects in the two larger forest patches as well as individual trees isolated in the grassland.

$673 \times 346 \mathrm{~mm}(300 \times 300 \mathrm{DPI})$ 


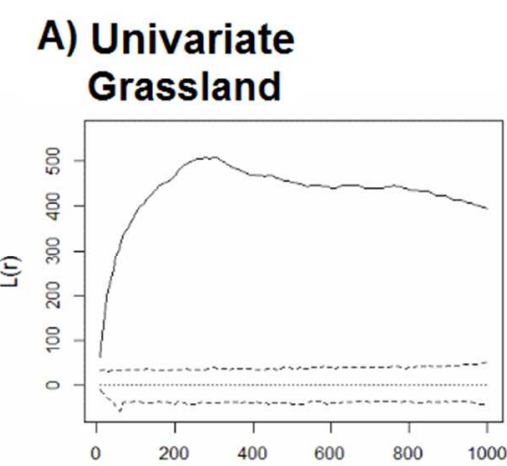

\section{B) Bivariate Grassland x Forest Patches}

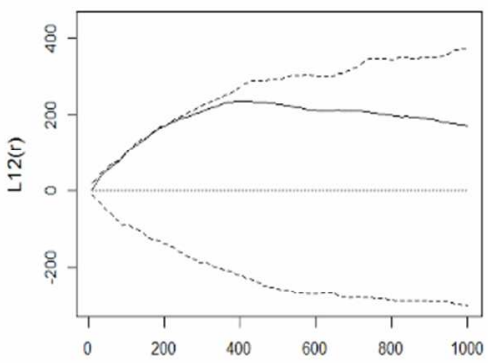

\section{C) Bivariate Survivorship}

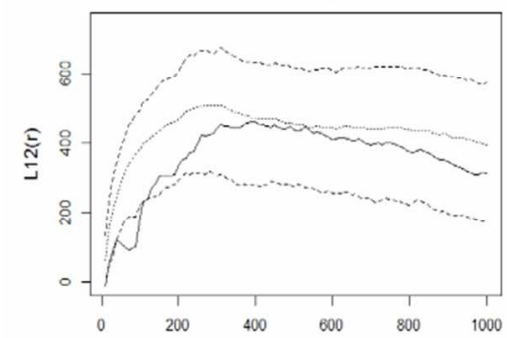

\section{D) Marked Crown Growth}

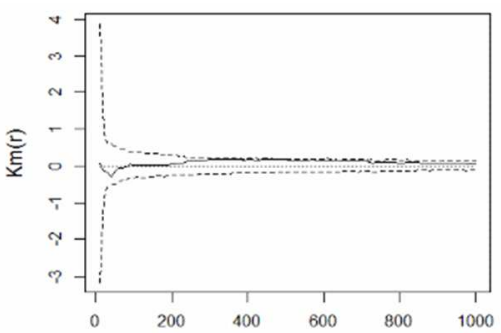

\section{E) Bivariate \\ Crown Shrinkage}

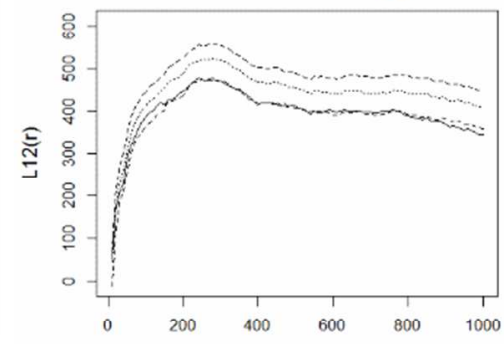

Distance (m)

Fig. 3. Spatial point pattern analyses. A) Univariate $L$ function for all trees in the grassland (solid line). B)

Bivariate $L$ function estimated for trees in the grassland and in forest patches. C) Bivariate $L$ function estimated for surviving and dying trees in the grassland. D) Crown growth marked Km function estimated for trees in the grassland. E) Bivariate $L$ function estimated for trees with crown breakage and crown growth in the grassland. All graphs with a 99\% local confidence envelope obtained from 1000 Monte Carlo simulations (dashed lines). The horizontal dotted lines mark the absolute zero $\mathrm{L}$ or $\mathrm{Km}$ values. Graph regions where the spatial function is above the upper limit of the confidence envelope indicate significant aggregation ( $L$ or $\mathrm{Km}$ functions) or attraction (bivariate $L$ function) at the corresponding spatial scale in the horizontal axis. Graph regions where the spatial function is below the lower limit of the confidence envelope indicate significant uniform distribution ( $\mathrm{L}$ or $\mathrm{Km}$ functions) or repulsion (bivariate $\mathrm{L}$ function) at the corresponding spatial scale in the horizontal axis 

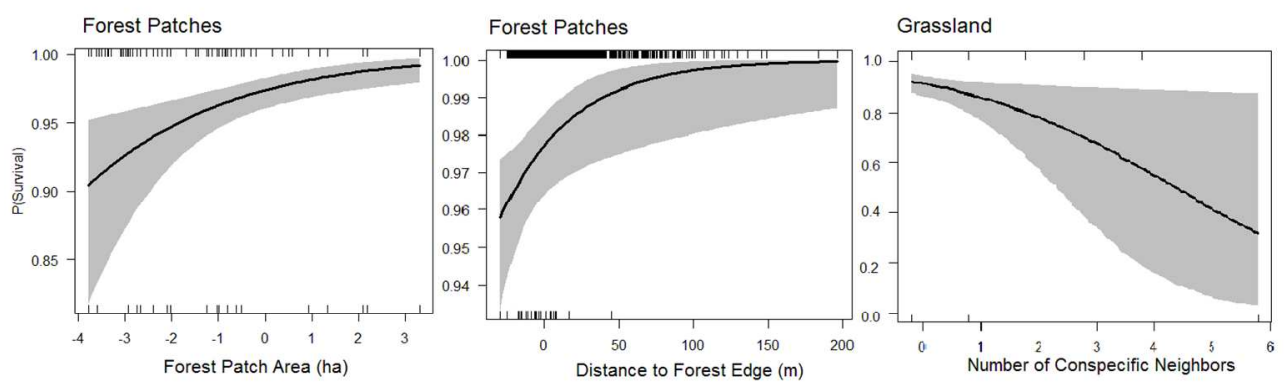

Fig. 4. Fitted binomial GLM models and $95 \%$ confidence bands (shaded areas) for the survival probability of adults of the conifer Araucaria angustifolia on forest patch area and distance to forest edge in forest patches and on the number of conspecific neighbours in grasslands in southern South America.

$127 \times 43 \mathrm{~mm}(300 \times 300 \mathrm{DPI})$ 